\title{
The influence of website quality and star rating signals on booking intention: analyzing the moderating effect of variety seeking
}

\section{La influencia de la página web y de la clasificación de estrellas como señales de calidad en la intención de reserva: análisis del efecto moderador de la búsqueda de variedad}

Website quality and star rating signals on booking intention

Received 21 September 2019 Accepted 26 June 2020

\section{网站质量与星级评分因素对预订意愿 的影响: 分析寻求多样化的调节作用}

Tamara Belver-Delgado

University of Salamanca, Salamanca, Spain

Sonia San-Martín

Department of Economy and Business Administration,

Faculty of Economics and Business, University of Burgos, Burgos, Spain, and

Rosa M. Hernández-Maestro

IME and Department of Business Administration, University of Salamanca, Salamanca, Spain

(C) Tamara Belver-Delgado, Sonia San-Martín and Rosa M. Hernández-Maestro. Published in Spanish Journal of Marketing - ESIC. Published by Emerald Publishing Limited. This article is published under the Creative Commons Attribution (CC BY 4.0) licence. Anyone may reproduce, distribute, translate and create derivative works of this article (for both commercial and non-commercial purposes), subject to full attribution to the original publication and authors. The full terms of this licence may be seen at http://creativecommons.org/licences/by/4.0/legalcode

This work was supported by the Ministry of Economy and Competitiveness (Spain), project ECO2017-82107-R.

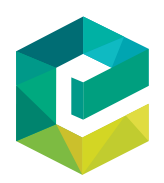

Spanish Journal of Marketing - 


\begin{abstract}
Purpose - The purpose of this study is to analyze the influence of booking website (hotel or third-party) characteristics and hotel star-rating classification, as signals of quality, on travelers' relationships with hotels or hotel chains, taking into account the moderating effect of travelers' tendencies to seek variety.

Design/methodology/approach - To test the hypothesized relationships, structural equation modeling was performed. A multi-group analysis was also conducted to test the moderating effect of travelers' variety seeking.

Findings - Both booking website quality and star rating improve customer satisfaction with specific experiences at hotels and behavioral intentions toward hotels. The results also show that travelers' varietyseeking levels (low/high) exert a moderating effect on their overall relationships with hotels, and quality signals are more relevant for those who are less inclined to seek variety in their travel experiences.

Originality/value - This paper analyzes the importance of quality signals on travelers' relationships with hotels in an electronic shopping environment. Furthermore, the influence of travelers' variety-seeking in the hotel sector in particular is studied. For hotel managers, a better knowledge of this personality trait can help to apply successful segmentation strategies.
\end{abstract}

Keywords Variety seeking, Signaling theory, E-commerce, Satisfaction, Behavioral intentions, Hotels

Paper type Research paper

\title{
Resumen
}

Propósito - Este estudio analiza la influencia de las características del sitio web de reserva -web propia del hotel o de un tercero- y del número de estrellas del hotel, como señales de calidad, en la relación del cliente con el hotel o cadena, teniendo en cuenta el efecto moderador de la tendencia del viajero a buscar variedad.

Diseño/metodología/enfoque - Para probar las hipótesis, se llevó a cabo un modelo de ecuaciones estructurales (SEM). También se realizó un análisis multi-grupo para probar el efecto moderador de la búsqueda de variedad del viajero.

Resultados - Tanto la calidad del sitio web de reserva como las estrellas favorecen la satisfacción del cliente con la experiencia concreta en el hotel y, finalmente, las intenciones de comportamiento hacia el hotel. Además, el análisis muestra que el nivel de búsqueda de variedad del viajero (bajo/alto) ejerce un efecto moderador en su relación global con el hotel y que las señales parecen ser más relevantes para los individuos con menor tendencia a buscar variedad en sus experiencias de viaje.

Originalidad/valor - Este trabajo analiza la importancia de las señales de calidad en la relación de los viajeros con los hoteles en un entorno de compra electrónica. Además, se estudia la influencia de la búsqueda de variedad de los viajeros en el sector hotelero en particular. Un mejor conocimiento de este rasgo de la personalidad puede ayudar a los gerentes de hotel a aplicar estrategias de segmentación exitosas.

Palabras clave Búsqueda de variedad, Teoría de señales, Comercio electrónico, Satisfacción, Intenciones de comportamiento, Hoteles

Tipo de artículo Trabajo de investigación

\section{摘要}

目的 - 本㸴究的目的是分析作为品质判断因素的预订网站(酒店或第三方)特征和酒店星级评分分类 对游客与酒店或连锁酒店关系的影响，并考虑游客寻求多样性倾向的调节作用。

文章设计/㸴究方法 - 为了检验假设的关系, 我们进行了结构方程建模。本研究还采用多组分析的 方法来检验旅客的多样性寻求的调节作用。

硎究结果 - 预订网站的质量和星级评分都可以提高客户对酒店具体体验的满意度和对酒店的行为意 向。结果还表明, 游客的多样性寻求水平(低/高)对他们与酒店的整体关系具有调节作用, 而质量因 素对那些不太倾向于在旅行体验中寻求多样性的人更相关。

本文独创性/价值 - 本文分析了在电子购物环境下, 品质因素对游客与酒店关系的重要性。此外, 本文还特别研究了游客的多样性寻求对酒店行业的影响。对于酒店管理者来说, 更好地了解这一个 性特征有助于成功地应用细分策略。

关键词 - 寻求多样性, 信号理论, 电子商务, 满意度, 行为意向, 酒店 


\section{Introduction}

In Spain, the tourism sector is essential. According to the National Institute of Statistics (INE), in 2018 tourism activity in the Spanish economy reached 12.3\% of gross domestic product (GDP) and $12.7 \%$ of total employment [National Institute of Statistics (INE), 2019b]. Hotels were the most popular form of accommodation: Of more than 467 million total overnight stays, $72 \%$ were in hotels [provisional data, National Institute of Statistics (INE), 2019a].

As a fundamental part of the tourism sector, hotels are favored by the increasing use of the internet and associated technologies, which allow hotels to improve productivity by simplifying and improving processes, reducing operating costs and interacting with consumers more effectively (Barreda et al., 2016; Theodosiou and Katsikea, 2012). In 2018, lodging reservations and travel packages booked online reached $15.1 \%$ of total spending on electronic commerce (e-commerce) in Spain (€ 6.287mn), with 15.2 million buyers and an average frequency of four annual purchases [National Observatory of Telecommunications and the Information Society (ONTSI), 2019].

These figures reveal the importance of the development of e-commerce through computer, tablet or mobile devices for tourism companies in general and hotel companies in particular. However, it is significant that in the case of lodging reservations and tour packages, most internet users who ultimately booked offline used the internet during their searches [National Observatory of Telecommunications and the Information Society (ONTSI), 2019], showing there are some limits to e-purchase. Today, consumers tend to combine various channels (digital and traditional) during the purchase process with the delivery of a holistic experience; that is, they exhibit omnichannel behavior (Rodríguez-Torrico et al., 2017; Viejo-Fernández et al., 2019). Moreover, the development of Information and Communication Technologies (ICT) provides many tools or applications that allow the consumer to plan a trip in a personalized and collaborative way (eTourism 2.0), such as travel social networks and virtual communities (Hernández-Méndez and Muñoz-Leiva, 2015). However, recent studies show that perceived risk still negatively affects the online purchase intentions of tourist services (Amaro and Duarte, 2015; Fong et al., 2017), and it should be taken into account that consumer dissatisfaction with the buying process or journey can affect the loyalty formation of certain consumer segments toward the company (Herhausen et al., 2019).

Given the high level of competition in the tourist accommodation sector, and the particular characteristics of services that make it difficult for consumers to determine quality prior to use or experience, it is key for hotels to provide signals of quality that reduce consumer uncertainty, increase satisfaction and establish long-term client relationships. These mechanisms, which are important in offline shopping, are essential in electronic environments, in which consumers perceive greater levels of risk (San-Martín and Camarero, 2009).

Customers' experiences with services are conditioned by each touchpoint (Herhausen et al., 2019). In the case of hotels, the attributes and characteristics of both the services themselves and related purchase or booking channels can determine customers' overall experiences and preferences. Thus, in this research, our first objective is to analyze the influences of booking website (hotel or third-party) characteristics and star rating - as signals of quality - on clients' relationships with accommodations, and particularly their satisfaction following specific hotel experiences and behavioral intentions toward hotels/ hotel chains. Our second objective is to analyze whether travelers' propensities to seek variety condition these relationships: We study the possible moderating effect of travelers'
Website quality and star rating signals on booking intention 
SJME

25,1

variety-seeking tendencies on their overall relationships with hotels and on the effect of quality signals on these relationships.

The contributions of this study to hotel sector literature are twofold. First, it applies Signaling Theory to explain the development of the relationship between travelers and hotels in an electronic context. Second, it analyzes the influence of quality signals on travelers' relationships with accommodations, according to individual travelers' levels of variety seeking in their travel experiences. To the best of our knowledge, there is no similar work in tourism literature.

The structure of the paper is as follows. In Section 2, we examine the mechanisms used by companies to provide quality signals to users, and we conduct a theoretical review of consumers' behavioral intentions and their determinants, applying Theory of Reasoned Action (TRA; Fishbein and Azjen, 1975). Complementarily, literature related to variety seeking was also examined. In Section 3, we describe the empirical analysis that we use to evaluate our proposed model and hypotheses. Finally, in Sections 4 and 5, we provide our results and present our conclusions, together with some limitations of our study and suggestions for future lines of research.

\section{Literature review}

\subsection{Booking website quality and hotel star rating as quality indicators}

According to Agency Theory, travelers face adverse selection problems or the existence of pre-contractual information asymmetry when choosing suppliers (Bergen et al., 1992). This asymmetry of information increases in electronic environments (Casaló et al., 2015; SanMartín and Jimenez, 2017). Therefore, Signaling Theory suggests that companies (evendors) use certain mechanisms or signals to help consumers infer the unobservable qualities of their products, services and behavior, thereby reducing uncertainty (Chen $e t$ al., 2010; Kirmani and Rao, 2000). Such signals also reduce information processing or heuristics and help consumers evaluate the quality of experiential products (Melo et al., 2017), such as hotel services. Accordingly, this study analyzes how booking website characteristics and stars of a hotel act as signals that help travelers accurately evaluate hotels services and encourage them to enter into long-term relationships with hotels or hotel chains.

Website quality can be defined as "users' evaluations of whether a website's features meet users' needs and reflect the overall excellence of the website" (Chang and Chen, 2008, p. 821). To evaluate the quality of hotel booking websites - and therefore their performance relevant features and attributes are commonly used, such as privacy and security policies, quality of information, discounts, convenience or perceived ease of use/reservation and design (Hahn et al., 2017; Jeon and Jeong, 2017; Kim et al., 2006; Li et al., 2017).

First, the privacy and security policies are the measures or procedures by which the personal and transactional data of users are protected from leakage or loss (Liao and Shi, 2017). The perception of information security improves the perceived value of online tourism services and the users' intention to use them (Liao and Shi, 2017; Ponte et al., 2015). Second, website information quality relates to the provision of complete, relevant information that allows comparisons among hotels, facilitates the booking process and results in better purchasing decisions (Wang and Wang, 2010). Third, of this content, discounts are a strategic variable that influence consumers' decisions to book, on either hotel or intermediaries' websites (Noone and Mattila, 2009). Fourth, we also analyze perceived ease of use, that is, lack of effort required to use booking websites and their reservation systems (Kim et al., 2006); this factor relates to quality of website navigation and organization (Tankovic and Benazic, 2018). Finally, we highlight the important role of the design and visual elements of Web pages in users' enjoyment and creation of positive attitudes (Carlson 
and O' Cass, 2011; Dedeke, 2016). The study by Jiang et al. (2016) showed that perceived website aesthetics had a positive influence on perceived utility and attitudes toward the website, which affects the corporate image exhibited via the website. Design includes features such as colors, the layout of text, graphics, photographs, videos and virtual tours (Phelan et al., 2011).

The internet allows consumers to compare the offers of multiple service providers, book or pay conveniently and reduce their search time (Fernández-Herrero et al., 2018). Mobile devices in particular provide ubiquity and the benefits of geolocation (Park and Huang, 2017). Online hotel booking therefore implies certain advantages or benefits compared with traditional purchase or booking methods (e.g. travel agency, telephone). Therefore, we anticipate that consumers perceive benefits when making online hotel reservations if the booking service provides appropriate, detailed information, offers quick response and processing, and adaptation to consumers' specific needs. The benefits perceived by consumers favor positive attitudes toward online purchase of travel services (Amaro and Duarte, 2015) and are important motivators of online hotel reservations (Park and Huang, 2017).

However, consumers' use of the internet on digital devices also involves risk because of difficulty in evaluating products/services, problems posed by privacy or security associated with online transactions and perceived complexity or difficulty of use (Fong et al., 2017; SanMartín and Jimenez, 2017). Consumer's perceptions of risk or uncertainty related to purchase decisions (Chang and Tseng, 2013) depend not only on products or services and the companies that market them but also on the purchase channels involved (San-Martín and Camarero, 2009). Perceived risk is associated with tension or anxiety caused by online purchasing (because of the possibility of failed transactions or individual errors) (Park and Huang, 2017; San-Martín et al., 2011) and it may affect travelers' online shopping attitudes and intentions (Amaro and Duarte, 2015; Chang and Chen, 2008; Fong et al., 2017). Thus, this study analyzes travelers' perceptions of the risks associated with making hotel reservations online compared with the risk of doing so offline; we predict travelers perceive risks if making online reservations is difficult or perceived as difficult, if they perceive a lack of privacy or security, and if the process involves greater uncertainty than other reservation methods.

Previous analyses of the hotel sector suggest that website quality favors the development of positive attitudes and encourages intentions to use or purchase online (Morosan and Jeong, 2008; Wang et al., 2015). Therefore, if booking websites meet travelers' needs and are effective, travelers will perceive greater benefits when booking accommodation online and experience less uncertainty than they do on other channels. Accordingly, we propose that booking website quality increases the benefits and reduces the perceived risks of online hotel reservations. We also propose that booking website (hotel or third-party) quality positively influences satisfaction with a specific hotel experience. Previous literature shows that perceived website quality favors satisfaction with an electronic shopping experience (Jeon and Jeong, 2017). In the online context, the website is the point of contact with the company. Thus, website quality can influence the overall evaluation of the purchase process and the perceptions of service quality (Pereira et al., 2016), and, in this way, it can affect the overall consumer experience with the firm. Therefore, the following research hypotheses are proposed:

H1a: Perception of booking website quality (privacy and security policies, quality of information, discounts, ease of use and design) positively influences the perceived benefits of online hotel reservations.
Website quality and star rating signals on booking intention 
SJME

25,1

8

Positive experiences associated with online booking can influence consumers' evaluations of hotels as part of their overall experiences. Tourists' self-planning of trips, that is, their intensity of internet use when seeking information, booking and paying for tourist services, favors their overall trip satisfaction (Fernández-Herrero et al., 2018).

These advantages or perceived benefits favor satisfaction with the booking process and improve satisfaction with specific hotel experiences. Conversely, perceptions of risk have negative effects on satisfaction with the booking process and with hotel stays. Thus, we propose:

H2: Perceived benefits of online hotel reservations positively influence satisfaction with a specific hotel experience.

H3: Perceived risks of online hotel reservations negatively influence satisfaction with a specific hotel experience.

In the lodging industry, star rating, or the number of stars (1-5), represents an official classification system that requires companies to meet certain technical and physical requirements. In general, a higher category (more stars) is associated with better facilities and equipment (Abrate et al., 2011), higher level of hospitality (Ariffin and Maghzi, 2012) and higher price (Martín-Fuentes, 2016). A higher ranking also signals a better reputation of a hotel company (Abrate and Viglia, 2016; Radojevic et al., 2015) or stronger guarantee of its capacity, reliability and integrity (San-Martín et al., 2015). Reputation plays an important role in reducing the perceived risk of hotel booking (Sun, 2014). Thus, a hotel's star rating represents commitments or explicit promises of the quality of physical attributes and level of service, and, at the same time, it is a proxy for prestige, reputation and price (Abrate and Viglia, 2016; Abrate et al., 2011; Ariffin and Maghzi, 2012).

Therefore, according to Signaling Theory, star rating acts as a signal or cue of the overall quality and reputation of hotels; it diminishes uncertainty by helping consumers infer information about hotel characteristics. We predict this signal will influence clients' expectations or beliefs about service delivery, foster predispositions or attitudes toward hotels and determine subsequent satisfaction with hotel stays. We predict that if service received in a hotel/hotel chain meets or exceeds expectations (generated by the number of stars perception), customers will be satisfied with the experience:

$H 4 a$ : Hotel star rating perception positively influences overall attitudes toward a hotel.

$H 4 b$ : Hotel star rating perception positively influences satisfaction with a specific experience at a hotel.

\subsection{Relationships between travelers and hotels}

According to previous studies, consumers' attitudes influence evaluations of received services (Hernández-Maestro et al., 2007; Sukhu et al., 2019) and determine their behavioral intentions (Amaro and Duarte, 2015). Fishbein and Azjen (1975) define attitude as a 
predisposition to respond negatively or positively to a certain object; it can manifest in three types of responses: cognitive, affective and behavioral (Casaló et al., 2015).

Consumer attitude toward a firm refers to general feelings developed prior to a service experience, which are determined by information received and past experiences (Ekinci et al., 2008). If travelers develop favorable attitudes toward a hotel, they tend to perceive their experiences in that hotel more positively and evaluate the hotel in a like manner. Therefore, we expect that overall positive attitudes toward hotels - that is, positive prior predispositions - increase satisfaction following experiences with the hotels:

H5: Overall positive attitudes toward a hotel positively influence satisfaction with a specific experience at the hotel.

In this study, loyalty is analyzed from an attitudinal perspective, which is the commitment or desire of consumers to maintain relationships with organizations (Wong et al., 2015). According to the TRA, we use consumers' behavioral intentions as a predictor of their behaviors toward hotels (Fishbein and Azjen, 1975), including their intentions to revisit, recommend and pay more.

The effect of customer satisfaction on behavioral intentions has been widely addressed in the tourism and hospitality literature (El-Adly, 2019; Sánchez-Fernández et al., 2020; Sohn et al., 2016; Su et al., 2016; Williams and Soutar, 2009). Satisfaction results from the evaluation of received services relative to previous expectations (Lai and Hitchcock, 2017), hence the current study analyzes travelers' satisfaction with their most recent hotel/hotel chain experiences, and we defined it as their evaluative and emotional responses following specific experiences with hotels.

If consumers are satisfied with their hotel experiences, they are more likely to revisit the properties, recommend them to others and even tolerate future price increases. Accordingly, we propose:

H6: Satisfaction with a specific experience at a hotel positively influences behavioral intentions toward the hotel.

\subsection{Moderating role of travelers' variety seeking}

Variety seeking in consumption situations refers to the tendency of individuals to seek different products or services (Baltas et al., 2017). True variety seeking prompts changing the product, brand or provider because of the stimulation inherent to change, triggered by curiosity or prevention of boredom and satiation (Berné et al., 2001; Ellis and Mattison Thompson, 2018). It relates to the personality trait known as optimal stimulation level (OSL) (Michaelidou, 2012; Olsen et al., 2016). According to OSL Theory, each person needs a certain level of stimulation or an appropriate level of stimulation (optimal); to maintain this level, people increase or decrease exploratory behaviors such as seeking variety or novelty (Ha and Jang, 2013a). In general, those with higher OSL are more likely to seek new stimuli than those with lower OSL (Ha and Jang, 2013a; Inman, 2001). Individuals' OSL and, therefore, variety seeking, is in turn associated with other personality characteristics (Ha and Jang, 2013a). Olsen et al. (2016), for example, found that openness to experience and extraversion are positively associated with tendency to seek variety, whereas neuroticism and conscientiousness negatively influence this conduct. Further, variety seeking may be related to consumer moods states (Chien-Huang and Hung-Chou, 2012).

The propensity to seek variety also relates to sensation seeking, that is, the search for varied, novel and complex experiences or sensations and the desire to face risks in favor of
Website quality and star rating signals on booking intention 
SJME

25,1

10

such experiences (Olsen et al., 2016). In the retail sector, Lashkova et al. (2019) show that sensory experiences involve learning that generates new and higher consumer expectations, making consumers more demanding and leading them to explore or seek new sensations and alternatives.

The (intrinsic) tendency to seek variety also depends on the product category involved (Martenson, 2018; Van Trijp et al., 1996); it is greater for products that have more hedonic attributes, such as tourism and leisure services (Bigné et al., 2009). Hedonic products are associated with sensory attributes; they stimulate variety-seeking behavior to avoid specific sensory satiety (Baltas et al., 2017). In the tourism sector for example, variety seeking can moderate intentions to return to the same destination (Barroso et al., 2007; Sánchez-García et al., 2012) and can be a key factor in travelers' decision-making (Legohérel et al., 2015).

Noting this negative effect that a propensity to seek variety can have on the formation of consumer loyalty, especially in relation to products with hedonic attributes such as hotel services, and their relevance to company strategies, we analyze the possible moderating effect of travelers' variety seeking on their overall relationships with hotels or hotel chains. Moreover, variety seeking relates to a willingness to face risks, by virtue of the consumption experience, hence we study whether high or low tendencies of travelers to seek variety in their travel experiences moderate the influence of quality signals (star rating and booking website quality) in their relationships with hotels. As previously indicated, quality signals or cues can help consumers infer information about accommodation and reduce their perceived uncertainty, leading them to evaluate hotels favorably and be satisfied with their service experiences. However, these signals may not have the same relevance to attitudes created toward hotels in the face of desire for change or the need to seek new stimuli. Accordingly, we propose the following research question with regard to the moderating effect of travelers' variety seeking:

$R Q$ : Does the tendency of travelers to seek variety moderate the relationships proposed in $H 1$ to $H 6$ ?

Figure 1 displays the hypotheses and the additional RQ of this research.

Figure 1.

Research model and hypotheses

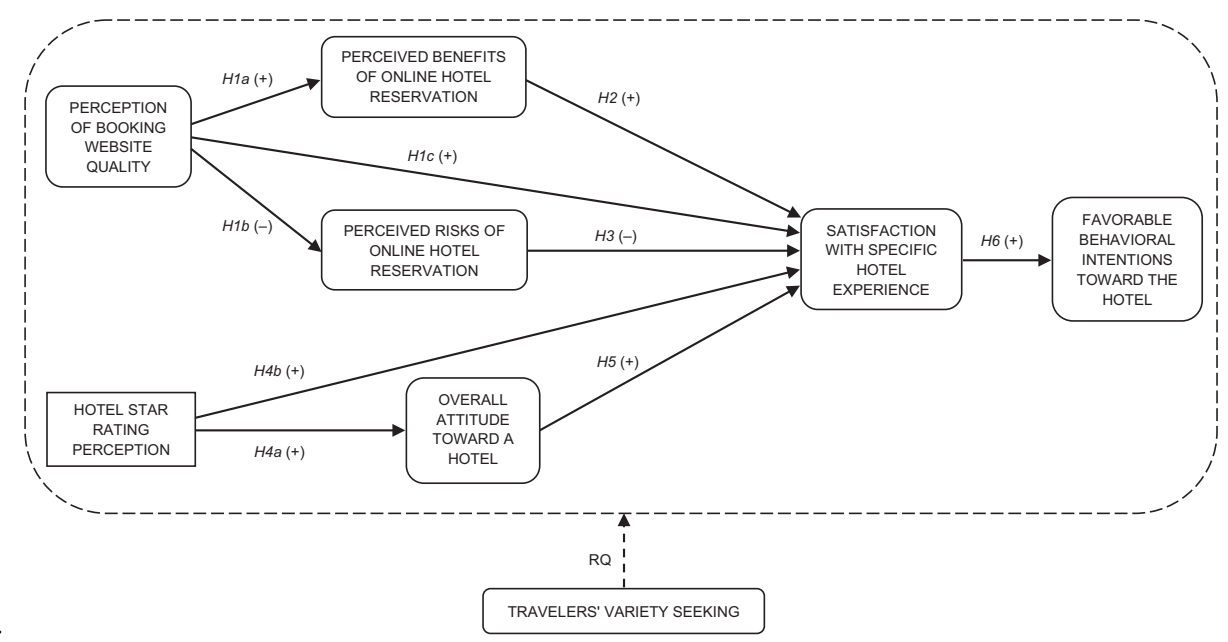




\section{Methodology}

To investigate our hypotheses, we analyzed information provided by a sample of 175 people who had stayed in hotels or apartment hotels during the previous six months and who had made their reservations online. We collected data through both personal and online surveys from January to March 2015, using convenience and snowball (non-probabilistic) sampling. This approach is similar to other hospitality studies, such as that by Kim and Perdue (2013), Lien et al. (2015) and Sánchez-Fernández et al. (2020). For surveys carried out in person, we randomly selected various public places, such as bus or train stations, to detect those who had stayed in hotels or hotel chains during the previous six months and who expressed their willingness to respond to our questionnaire about their most recent hotel stay and their reservations made using electronic devices (computer, tablet, or mobile phone). The first section contained questions about specific data of the hotel such as the name, number of stars, location, type of hotel (urban, coastal or rural) and whether or not it belonged to hotel chain and questions about this trip (trip mode and motivation). The second section of the questionnaire contained questions regarding booking process of the hotel and the evaluation of the stay, and expressions such as "that hotel" or "the last hotel you stayed in" were always included in the questions to ensure that all respondents kept in mind the last hotel they had stayed in. The third section contained questions about general travel preferences and the last section contained questions regarding respondent's demographic characteristics.

The questionnaire was developed from reliable and valid scales from previous literature. Table 1 shows the scales used to measure the variables of the proposed model. All items were measured through five-point Likert scales.

We asked respondents to indicate: To what extent they considered the number of stars to be important (1-5) at the time of choosing their hotel and the importance they gave to booking website characteristics. We adapted the perceived quality of the website scale from work by Kim et al. (2006), Wong and Law (2005) and Rong et al. (2009). To measure satisfaction, we adapted the scale of Han et al. (2011), and for consumers' behavioral intentions and attitudes toward hotels, we used as a reference Kim and Kim's (2005) work. We based the measurement of perceived benefits and risks of online hotel reservations on Wang and Wang (2010). Finally, we adapted the measure of variety seeking from Álvarez and Asugman (2006). For these scales, we asked respondents to indicate their degree of agreement or disagreement with the proposed items $(1=$ "strongly disagree", 5 = "strongly agree").

The sample was composed of $64 \%$ women and $36 \%$ men. Most respondents were between 31 and 50 years of age (51.4\%), had higher education $(80.6 \%)$ and were workers $(77.8 \%)$, similar to the traveler profile of other Spanish tourism studies (SEGITTUR, 2014) and the online shopper profile of e-commerce studies [Interactive Advertising Bureau (IAB Spain), 2019]. Most had been internet users for more than six years $(88.6 \%)$.

With regard to characteristics of trips taken by respondents, most were national (68\%) rather than international ( $32 \%$ ); respondents' foremost reason for travel was to visit a city $(36.6 \%)$, followed by enjoyment of the beach $(17.7 \%)$ and most respondents traveled in a couple $(51.4 \%)$. For more than half the sample, the duration of stay was two to four nights $(51.4 \%)$, mainly in urban hotels/hotel chains $(73.7 \%)$. Most hotels were 4 -star $(45.1 \%)$, followed by 3 -star $(34.9 \%)$, and there were no significant differences between the percentage of lodgings in hotel chains $(52.6 \%)$ and independent hotels $(47.4 \%)$. The great majority of respondents had stayed at their hotels for the first time $(84.6 \%) ; 100 \%$ had used the internet to make their bookings. Computers were the main booking devices $(88.6 \%)$, followed by tablets $(8 \%)$ and mobile devices $(3.4 \%)$. With regard to booking websites, most respondents
Website quality and star rating signals on booking intention 


\begin{tabular}{|c|c|c|}
\hline Construct & Items & Description \\
\hline \multirow[t]{10}{*}{$\begin{array}{l}\text { Perception of booking } \\
\text { website quality }\end{array}$} & BWQ1 & $\begin{array}{l}\text { Security of sensitive information (e.g., credit card } \\
\text { data) }\end{array}$ \\
\hline & BWQ2 & Appropriate products/services information \\
\hline & BWQ3 & Variety of products/services choice \\
\hline & BWQ4 & Price with discounts \\
\hline & BWQ5 & Ease of use of website \\
\hline & BWQ6 & Ease of making hotel reservation \\
\hline & BWQ7 & Ease of canceling hotel reservation \\
\hline & BWQ8 & Easy payment procedure \\
\hline & BWQ9 & Visually attractive information \\
\hline & BWQ10 & Inclusion of photos of hotel facilities \\
\hline \multirow{6}{*}{$\begin{array}{l}\text { Hotel star rating perception } \\
\text { Perceived benefits of online } \\
\text { hotel reservation }\end{array}$} & $\mathrm{STA1}^{\mathrm{a}}$ & Importance of stars at the time of choosing the hotel \\
\hline & & The use of online booking service... \\
\hline & PB1 & ...gave me detailed information \\
\hline & PB2 & ...gave me timely information \\
\hline & PB3 & ...gave me a quick response and processing \\
\hline & PB4 & . . adapted to my specific needs \\
\hline \multirow{4}{*}{$\begin{array}{l}\text { Perceived risks of online hotel } \\
\text { reservation }\end{array}$} & & The use of online booking service. . \\
\hline & PR1 & ...was difficult \\
\hline & PR2 & ...put my privacy in danger \\
\hline & PR3 & $\begin{array}{l}\text {...compared to other methods, meant more } \\
\text { uncertainty }\end{array}$ \\
\hline \multirow{2}{*}{$\begin{array}{l}\text { Overall attitude toward the } \\
\text { hotel }\end{array}$} & ATT1 & When I travel to the same destination, I usually use \\
\hline & ATT2 & $\begin{array}{l}\text { this hotel as my first choice compared to other hotels } \\
\text { I regularly visit this hotel }\end{array}$ \\
\hline \multirow[t]{2}{*}{$\begin{array}{l}\text { Satisfaction with experience } \\
\text { at a hotel }\end{array}$} & SAT1 & $\begin{array}{l}\text { The level of satisfaction with this hotel is quite close } \\
\text { to my ideal hotel }\end{array}$ \\
\hline & SAT2 & My decision to stay in this hotel was intelligent/wise \\
\hline \multirow[t]{3}{*}{$\begin{array}{l}\text { Favorable behavioral } \\
\text { intentions toward the hotel }\end{array}$} & INT1 & $\begin{array}{l}\text { If I returned to the same destination in the future, I } \\
\text { would even be willing to pay something more for } \\
\text { this hotel than I paid }\end{array}$ \\
\hline & INT2 & I intend to visit this hotel again \\
\hline & INT3 & I would recommend this hotel to others \\
\hline
\end{tabular}

Table 1.

Measurement scales

Note: ${ }^{\text {amono-item }}$

had made their reservations on intermediary booking websites (65.1\%), followed by hotel/ hotel chain websites $(29.7 \%)$.

\subsection{Analysis by partial least squares- structural equation modeling}

We tested our hypotheses through structural equation modeling (SEM), using the partial least squares (PLS) approach and SmartPLS 3 software (Ringle et al., 2015). This methodology is appropriate when the study goal is to predict and develop theory (Reinartz et al., 2009). We also selected PLS to avoid any distributional assumption of the observed variables and because it is a robust technique for limited samples (Chin, 2010; Hair et al., 2014). We followed the two-step process indicated by Hair et al. (2014). The first step includes the assessment of the measurement (outer) model; the second step involves the assessment of the structural (inner) model and the evaluation of the relationships between the constructs, as specified by the research model. 
3.1.1 Evaluation of the measurement model. As Table 2 shows, all indicator loadings were above the 0.6 cut-off (Henseler et al., 2009). Furthermore, the composite reliability (CR) and Cronbach's alpha $(\alpha)$ values were equal or superior to 0.7, the Spearman correlation (rho_A) was higher than 0.7 , and the average variance extracted (AVE) was greater than 0.5 for each latent construct, thereby confirming the reliability and validity of the measurement model.

Next, we checked for discriminant validity according to three complementary criteria (Table 3 and Table 4). The square root of the AVE from each construct was greater than the correlation of the same with other constructs (Fornell and Larcker, 1981), the value of the Heterotrait-Monotrait (HTMT) ratio was less than 0.9 (Henseler et al., 2015), and the cross-loadings revealed that the correlation of each indicator with its construct was greater than the correlation of each indicator with other constructs (Chin, 1998). We also determined the statistical significance of the coefficients by using a bootstrapping re-sample procedure with 5,000 randomly generated subsamples (Hair et al., 2014).

\begin{tabular}{|c|c|c|c|c|c|c|c|}
\hline Construct/Items & Mean & $\mathrm{SD}$ & Loading & $\alpha$ & $\mathrm{CR}$ & rho_A & AVE \\
\hline Perception of booking website quality & & & & 0.97 & 0.97 & 0.97 & 0.79 \\
\hline BWQ1 & 4.47 & 1.04 & $0.93 * * *$ & & & & \\
\hline BWQ2 & 4.30 & 1.07 & $0.90 * * *$ & & & & \\
\hline BWQ3 & 4.07 & 1.08 & $0.87 * * *$ & & & & \\
\hline BWQ4 & 4.28 & 1.06 & $0.89 * * *$ & & & & \\
\hline BWQ5 & 4.22 & 1.15 & $0.86 * * *$ & & & & \\
\hline BWQ6 & 4.36 & 1.08 & $0.91 * * *$ & & & & \\
\hline BWQ7 & 4.35 & 1.07 & $0.90 * * *$ & & & & \\
\hline BWQ8 & 4.39 & 1.04 & $0.94 * * *$ & & & & \\
\hline BWQ9 & 4.00 & 1.13 & $0.82 * * *$ & & & & \\
\hline BWQ10 & 4.27 & 1.09 & $0.88 * * *$ & & & & \\
\hline Hotel star rating perception & & & & 1 & 1 & 1 & 1 \\
\hline STA1 $^{\mathrm{a}}$ & 3.30 & 0.97 & 1 & & & & \\
\hline Perceived benefits of online hotel reservation & & & & 0.88 & 0.92 & 0.88 & 0.73 \\
\hline PB1 & 4.14 & 0.82 & $0.88 * * *$ & & & & \\
\hline PB2 & 4.06 & 0.85 & $0.87 * * * *$ & & & & \\
\hline PB3 & 4.24 & 0.77 & $0.83 * * *$ & & & & \\
\hline PB4 & 4.19 & 0.81 & $0.84 * * *$ & & & & \\
\hline Perceived risks of online hotel reservation & & & & 0.74 & 0.85 & 0.78 & 0.66 \\
\hline PR1 & 1.55 & 0.93 & $0.79 * * *$ & & & & \\
\hline PR2 & 1.59 & 0.94 & $0.89 * * *$ & & & & \\
\hline PR3 & 1.91 & 1.06 & $0.75 * * *$ & & & & \\
\hline Overall attitude toward the hotel & & & & 0.71 & 0.87 & 0.87 & 0.76 \\
\hline ATT1 & 2.90 & 1.38 & $0.94 * * *$ & & & & \\
\hline ATT2 & 1.79 & 1.24 & $0.80 * * *$ & & & & \\
\hline Satisfaction with experience at a hotel & & & & 0.76 & 0.89 & 0.76 & 0.81 \\
\hline SAT1 & 3.33 & 1.16 & $0.90 * * *$ & & & & \\
\hline SAT2 & 4.00 & 0.86 & $0.90 * * *$ & & & & \\
\hline $\begin{array}{l}\text { Favorable behavioral intentions toward the } \\
\text { hotel }\end{array}$ & & & & 081 & 089 & 084 & 072 \\
\hline INT1 & 2.57 & 1.31 & $0.84 * * *$ & & & & \\
\hline INT2 & 2.96 & 1.36 & $0.84 * * * *$ & & & & \\
\hline INT3 & 3.89 & 1.08 & $0.87 * * *$ & & & & \\
\hline
\end{tabular}

Notes: $* * * * 0.001 ;{ }^{\text {a }}$ mono-item; $\alpha=$ Cronbach's alpha; $\mathrm{CR}=$ composite reliability; rho_A $=$ Spearman correlation; $\mathrm{AVE}=$ average variance extracted
Website quality and star rating signals on booking intention 13
Table 2.

Assessment of measurement model 
SJME

25,1

14

Fornell and Larcker criterion

1. Perception of booking website quality

2. Hotel star rating perception

3. Perceived benefits of online hotel reservation

4. Perceived risks of online hotel reservation

5. Overall attitude toward hotel

6. Satisfaction with experience at hotel

7. Favorable behavioral intentions toward hotel

$1 \quad 2$

3

4

5

$\begin{array}{ll}6 & 7\end{array}$

HTMT

1. Perception of booking website quality

2. Hotel star rating perception

0.89

3. Perceived benefits of online hotel reservation

0.04

0.41

$\begin{array}{ll}-0.18 & 0.01\end{array}$

$-0.02 \quad 0.28$

$0.31 \quad 0.29$

$0.24 \quad 0.24$

0.86

$-0.38$

0.12

0.50

0.81
0.08
-0.16
-0.06

0.87

$0.59 \quad 0.72$

0.85

4. Perceived risks of online hotel reservation

5. Overall attitude toward hotel

0.04

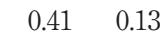

$\begin{array}{ll}-0.18 & 0.01 \\ -0.02 & 0.28\end{array}$

$0.31 \quad 0.29$

-0.38
0.12
0.50
0.38

0.08

$0.24 \quad 0.24$

$0.50-0.16$

0.45

7. Favorable behavioral intentions toward hotel

Notes: Regarding the Fornell and Larcker criterion, values in italic
construct correlations are shown off the diagonal, n.a.: non-applicable

Table 3.

Discriminant validity

Table 4.

Factor loadings (in italics) and cross loadings

\begin{tabular}{|c|c|c|c|c|c|c|c|}
\hline & BWQ & STA & PB & PR & ATT & SAT & INT \\
\hline BWQ1 & 0.931 & -0.001 & 0.310 & -0.136 & -0.023 & 0.284 & 0.224 \\
\hline BWQ2 & 0.902 & 0.022 & 0.415 & -0.194 & -0.002 & 0.268 & 0.191 \\
\hline BWQ3 & 0.872 & 0.002 & 0.439 & -0.212 & -0.035 & 0.246 & 0.199 \\
\hline BWQ4 & 0.891 & 0.119 & 0.398 & -0.160 & 0.066 & 0.333 & 0.263 \\
\hline BWQ5 & 0.861 & 0.013 & 0.302 & -0.137 & -0.031 & 0.227 & 0.168 \\
\hline BWQ6 & 0.905 & -0.044 & 0.270 & -0.139 & -0.036 & 0.243 & 0.163 \\
\hline BWQ7 & 0.903 & -0.027 & 0.329 & -0.126 & -0.076 & 0.230 & 0.166 \\
\hline BWQ8 & 0.937 & 0.008 & 0.363 & -0.156 & -0.035 & 0.318 & 0.237 \\
\hline BWQ9 & 0.816 & 0.116 & 0.366 & -0.174 & 0.011 & 0.292 & 0.273 \\
\hline BWQ10 & 0.877 & 0.080 & 0.373 & -0.175 & -0.046 & 0.299 & 0.248 \\
\hline STA1 $^{\mathrm{a}}$ & 0.037 & 1.000 & 0.130 & 0.013 & 0.284 & 0.290 & 0.237 \\
\hline PB1 & 0.335 & 0.179 & 0.882 & -0.400 & 0.127 & 0.443 & 0.306 \\
\hline PB2 & 0.337 & 0.144 & 0.868 & -0.255 & 0.123 & 0.457 & 0.340 \\
\hline PB3 & 0.344 & 0.025 & 0.832 & -0.322 & 0.115 & 0.404 & 0.302 \\
\hline PB4 & 0.379 & 0.093 & 0.843 & -0.328 & 0.060 & 0.412 & 0.365 \\
\hline PR1 & -0.137 & 0.061 & -0.330 & 0.788 & 0.092 & -0.081 & -0.071 \\
\hline PR2 & -0.193 & -0.009 & -0.352 & 0.885 & 0.068 & -0.144 & -0.020 \\
\hline PR3 & -0.104 & -0.008 & -0.239 & 0.753 & 0.030 & -0.148 & -0.057 \\
\hline ATT1 & 0.013 & 0.295 & 0.189 & 0.015 & 0.941 & 0.478 & 0.583 \\
\hline ATT2 & -0.074 & 0.178 & -0.029 & 0.162 & 0.802 & 0.264 & 0.418 \\
\hline SAT1 & 0.164 & 0.321 & 0.377 & -0.117 & 0.480 & 0.899 & 0.660 \\
\hline SAT2 & 0.396 & 0.199 & 0.524 & -0.164 & 0.327 & 0.897 & 0.626 \\
\hline INT1 & 0.119 & 0.245 & 0.208 & -0.001 & 0.507 & 0.559 & 0.843 \\
\hline INT2 & 0.130 & 0.175 & 0.284 & -0.025 & 0.593 & 0.494 & 0.842 \\
\hline INT3 & 0.327 & 0.188 & 0.447 & -0.098 & 0.434 & 0.729 & 0.868 \\
\hline
\end{tabular}

Note: ${ }^{\text {amono-item }}$ 
3.1.2 Evaluation of the structural model. We assessed the goodness of fit of the model according to the standardized residual root mean square (SRMR) (Henseler et al., 2015). A value below 0.10 indicates a good fit, and the SRMR value of this model was 0.089 . Thus, the model specification met the satisfactory threshold.

To evaluate the predictive validity of the research model, we examined the explained variance $\left(R^{2}\right)$ of the endogenous constructs (Chin, 2010), which indicates the amount of variance of the construct explained by the model (Table 5). In addition, we obtained StoneGeisser's $Q^{2}$ (Geisser, 1975; Stone, 1974), which is a criterion for analyzing the predictive capacity of dependent constructs and endogenous variables. We calculated the $Q^{2}$ values of the endogenous constructs using a blindfolding procedure $(D=8)$. In this model, all values obtained were greater than 0 (ranging from $0.018-0.341$ ), indicative of the predictive relevance of the endogenous constructs.

We also used the coefficient $f^{2}$ to measure whether an independent latent variable had a substantial impact on a latent dependent variable (Table 7). Values of $f^{2}$ equal to 0.02 to 0.15 , 0.15 to 0.35 , and 0.35 or higher indicate that an exogenous latent variable has a small, medium or large effect, respectively (Cohen, 1988).

3.1.3 Analysis of the moderating effect of travelers' variety seeking. After evaluating the measurement model and the structural model, we analyzed the moderating effect of the tendency of travelers to seek variety, as proposed in our research question. We formed the variety-seeking construct according to the following items: "When I travel, I like it to be an adventure/am looking to gain new experiences/prefer to go to places that I have not seen before". We divided the respondents into high propensity and low propensity for variety seeking groups using the median.

To study the moderator effect, we performed a multi-group analysis (MGA) using the SmartPLS3 program. Before running MGA, we tested the measurement invariance of composite models (MICOM). In this regard, Hair et al. (2012) and Henseler et al. (2016) advocate the test of measurement invariance before performing a multi-group SEM analyses to ensure the validity of MGA outcomes and conclusions. The MICOM tests were performed by using the permutation process in SmartPLS (5,000 permutations). The MICOM procedure involves three steps: configural invariance, compositional invariance and the equality of composite mean values and variances (Henseler et al., 2016). Configural invariance was established because the PLS path model setups are equal across the two groups, and groupspecific model estimations draw on identical algorithm settings. In addition, Table 6 shows that compositional invariance is fulfilled for all constructs; that is, for each construct $95 \%$ permutation-based confidence intervals comprise the correlation value between the construct scores in the first group and the construct scores in the second group; therefore, it can be said that the correlation is not lower than 1 and thus the construct does not differ much in either group. Finally, also taking into account equality of means and variances for each construct (Table 6), it is concluded that partial invariance is established for booking website quality, perceived benefits of online hotel reservation, satisfaction with experience

\begin{tabular}{|c|c|c|c|c|}
\hline Dependent constructs & $R^{2}$ & $R^{2}$ Adjusted & $Q^{2}$ & \\
\hline Perceived benefits of online hotel reservation & 0.166 & 0.161 & 0.114 & \\
\hline Perceived risks of online hotel reservation & 0.034 & 0.028 & 0.018 & \\
\hline Overall attitude toward hotel & 0.081 & 0.075 & 0.054 & \\
\hline Satisfaction with experience at hotel & 0.441 & 0.425 & 0.328 & Table 5. \\
\hline Favorable behavioral intentions toward hotel & 0.513 & 0.510 & 0.341 & Predictive validity \\
\hline
\end{tabular}

Website quality and star rating signals on booking intention

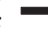


SJME

25,1

16

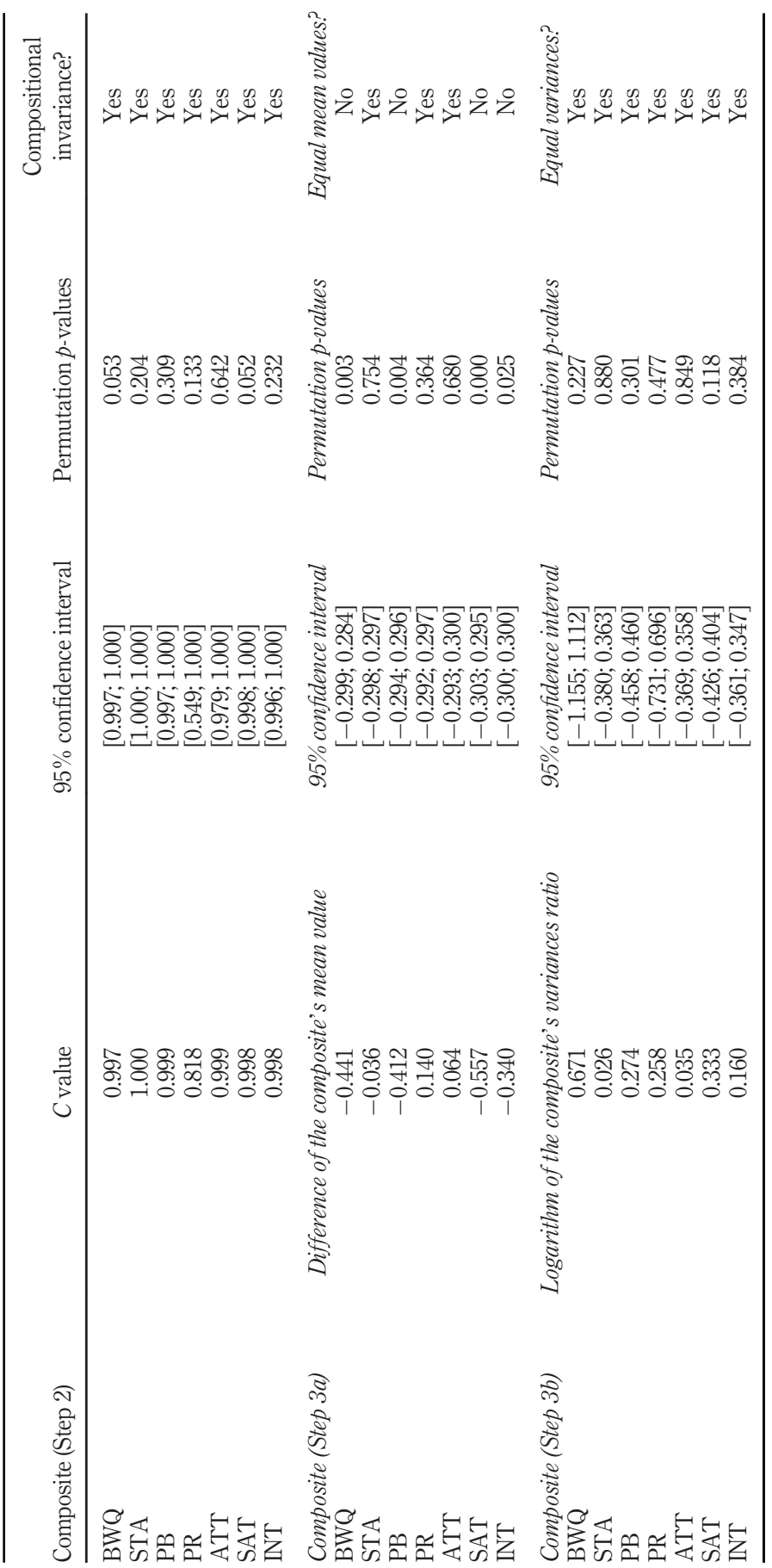

Table 6.

Measurement invariance of composite models Results 
at hotel, and favorable behavioral intentions; and full invariance is identified for hotel star rating, perceived risks of online hotel reservation, and overall attitude toward hotel.

\section{Results}

Table 7 shows the results of the hypotheses, with the exception of the moderating effect of variety seeking. All hypotheses except two (H1c and $H 3)$ were accepted.

In particular, the effect of the booking website quality on the perceived benefits of online hotel reservation $(\mathrm{Hl}$ a $)$ and the effect of the perceived benefits on satisfaction with experience at hotel (H2) are positive and significant $(\beta=0.407 ; t=6.160 ; p<0.001$ and $\beta=0.365 ; t=4.777 ; p<$ 0.001 , respectively), whereas the direct relationship between booking website quality and satisfaction with the experience at hotel $(H 1 c)$ is not significant $(\beta=0.162 ; t=1.759 ; p=0.079)$. In fact, the indirect effect between website quality and satisfaction, through perceived benefits in the online booking, is positive and significant $(\beta=0.152 ; t=3.332 ; p<0.01)$. And if we removed the perceived benefits variable from the model, the direct relationship between website quality and satisfaction would become significant $(\beta=0.287 ; t=3.526 ; p<0.001$ ). Therefore, in relation to the influence of booking website quality on satisfaction, the results reveal a full mediating effect of the perceived benefits variable.

Regarding the moderating effects (RQ), the non-parametric PLS-MGA test showed some significant differences among high and low variety-seeking groups (Table 8).

Specifically, if we considered a $90 \%$ confidence level, the non-parametric tests would show that the relationship between booking website quality and perceived benefits, as well as the relationship between hotel star rating and overall positive attitude toward a hotel, are significantly different for those with high and low variety-seeking behavior $(\phi<0.10)$. For both relationships (website quality-perceived benefits and star rating-overall attitude), the associated coefficients were lower for people in the high variety-seeking group, in comparison to people in the low variety-seeking group.

Moreover, the relationship between star rating and overall positive attitude toward a hotel is positive and significant for people in the low variety-seeking group, but it is not significant for individuals with a high propensity to seek variety (Table 8).

In addition, the relationship between overall attitude toward a hotel and satisfaction with a specific experience at a hotel, as well as the relationship between satisfaction and favorable behavioral intentions, are significantly different for those with high and low propensities to seek variety in their travel experiences $(p<0.01)$. These coefficients would again be lower for those individuals with a high propensity to seek variety. Consequently, these results indicate that variety-seeking is a moderating variable on the relationship between travelers and hotels.

\section{Discussion and implications}

The competitiveness of the tourist accommodation sector and the intangibility that characterizes both these services and the online context makes it critical for managers to offer quality signals that help reduce the uncertainty perceived by travelers. Ensuring customer satisfaction that helps foster lasting relationships with firms can be decisive in a sector in which consumers tend to seek new and varied consumer experiences (Ariffin and Maghzi, 2012).

This study contributes to the literature by:

- analyzing the effects of website booking features and hotel star rating on long-term customer relationships, and by

- examining how travelers' variety seeking (individual's personality trait) influences these relationships with hotels.
Website quality and star rating signals on booking intention 
SJME

25,1

18

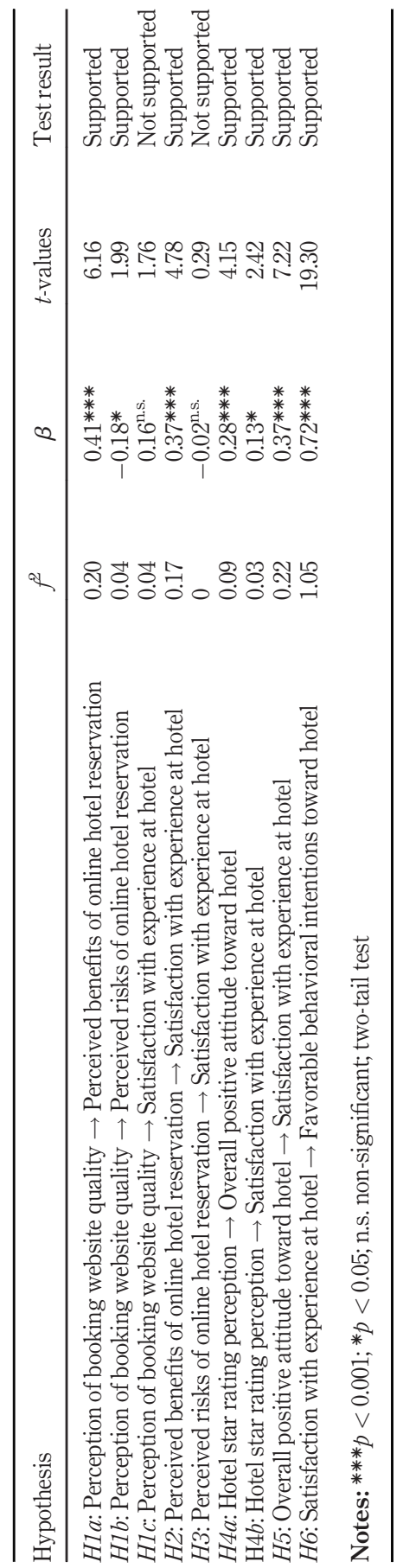

Table 7.

Results of the

structural model 


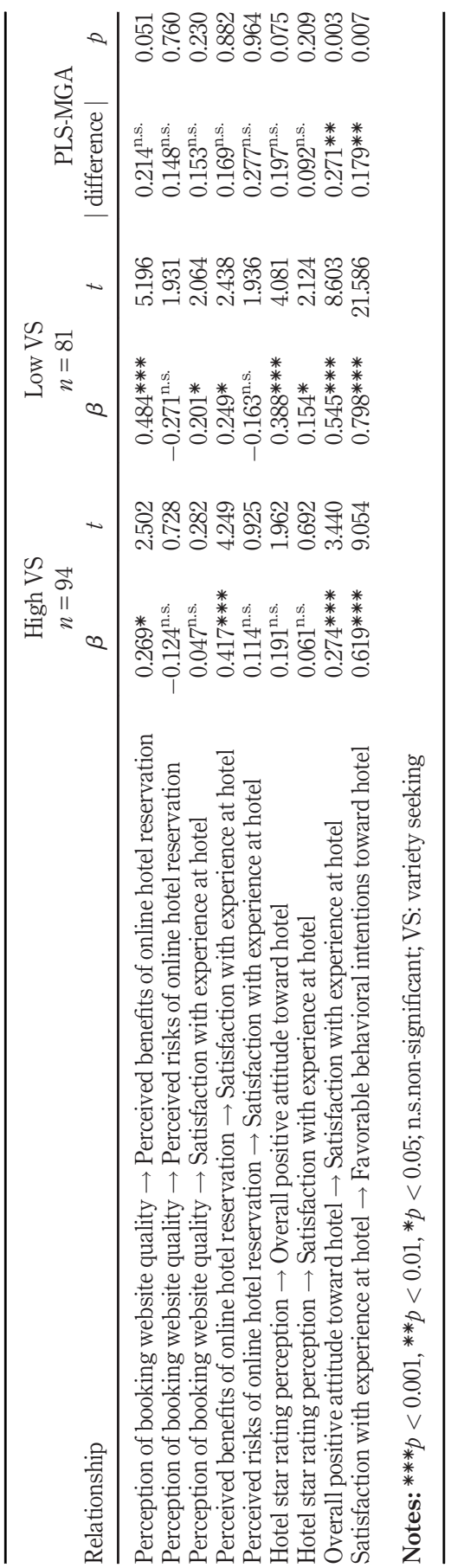

Website quality and star rating signals on booking intention

Table 8.

Results of multigroup analysis with partial least squares 
SJME

25,1

In particular, with regard to booking websites - both hotel websites and third-party websites -, the results show that if they provide security of sensitive information; include appropriate and visually appealing information about their products and services; inform users of offers or discounts; offer ease of use, reservations and cancelations; and include hotel-facility photographs, consumers perceive greater benefits and less risk of making online bookings. In short, consumers perceive higher value of online hotel booking compared with other channels. Therefore, booking websites should offer quality features that reflect the specific wishes and needs of users, reduce any difficulty of use and perceived uncertainty and provide positive shopping experiences. Website quality positively influences satisfaction with the virtual environment and satisfaction with the electronic shopping experience (e-satisfaction) (Jeon and Jeong, 2017; Pereira et al., 2016). Moreover, users' perceptions of advantages of buying online lead to positive attitudes toward online purchase of travel services (Amaro and Duarte, 2015) and act as motivators of hotel booking intentions (Park and Huang, 2017). Regarding how content and design of the website can influence user behavior, recent studies show that decision framing (combined package options/separate product options) in the travel bundle packages of the online travel intermediaries (OTAs) influences the tendency of variety seeking (Kim et al., 2018).

Our results also show that travelers' perceptions of benefits of booking online improve satisfaction with their specific experiences at hotels. Further, the results indicate that the effect of the booking website quality improves satisfaction with hotel stay, but this effect is completely mediated by the perceived benefits of booking online. We confirm the findings of previous studies, namely, that experience with the purchase or booking process is part of the overall consumption experience and determines subsequent evaluations (Fernández-Herrero et al., 2018; Sánchez et al., 2006). However, although perceived risks are antecedents of internet purchase intentions (Fong et al., 2017), in our analysis of our overall sample, we were not able to confirm the proposed relationship between perceived risks when booking online and satisfaction with the stay; it was negative but not significant. The explanation may be that even if individual consumers perceive some risks when booking hotels online, those risks are not significant enough to reduce satisfaction with hotel experiences. Moreover, some respondents may have stayed at certain hotels in the past and are already loyal to them in their evaluations.

Complementarily, the results indicate that classification by number of stars positively influences the overall attitudes of travelers toward hotels, their levels of satisfaction with specific experience at hotels, and their behavioral intentions toward hotels. Although the Núñez-Serrano et al. (2014) study suggested that the relationship between star rating and hotel quality is not so clear, the results of this work are consistent with Martín-Fuentes (2016). The Martín-Fuentes (2016) study found that star rating is positively related to the scores awarded by past users on third-party websites (TripAdvisor and Booking) or to greater user satisfaction, and with the price level of the hotel. According to Signaling Theory, star rating seems to act as a signal of the overall quality of hotels and their reputations through booking websites; it helps travelers infer information about accommodation, develop positive predispositions toward hotels and establish feelings of satisfaction with hotel stays. Our results suggest that categories or stars help minimize the differences between perceived service performance and consumers' expectations and lead to satisfaction with specific hotel experiences; they also increase consumers' desires to revisit hotels, recommend hotels to others and even pay more for the hotels in the future. In other words, travelers appear to be loyal to certain standards or hotel/hotel chain quality; for which reason this quality signal is considered an effective way for hotels to differentiate themselves (Becerra et al, 2013).

With regard to our second objective (examining how travelers' variety seeking influences their relationship with hotels), we find that for those with high tendencies to seek variety, 
booking website quality exerts less positive influence on consumers' perceived benefits and less negative influence on perceived risks when consumers book hotels online. The relationship between website quality and perceived benefits of making online reservations is significantly different for those with high versus low variety-seeking tendencies, although this difference is significant only at $90 \%$ of the confidence level. Perhaps those who are more inclined to seek new experiences and stimuli also are more likely to tolerate certain risks in favor of experiences in general and purchase or booking channels in particular. For this reason, booking website characteristics are less important as quality signals for travelers with high variety-seeking tendencies than for those with low tendencies, who are less prone to risks or losses when making online transactions and thus more dependent on quality signals when evaluating booking channels.

However, the positive influence of the perceived benefits of online booking on satisfaction with hotel stays is greater for those with high variety-seeking tendencies than for those with low tendencies; and the effect of perceived risks of online booking on satisfaction with hotel stays is negative and significant at $90 \%$ of the confidence level $(\phi=0.053)$ for those with low varietyseeking tendencies and not significant for those with high tendencies. In other words, those who are less likely to seek variety are less influenced by benefits and more influenced by the perceived risks of online booking when they evaluate their experience at hotels; this finding suggests they are less prone to innovation and the risks that innovation implies. In contrast, those who are more likely to seek variety - and therefore who have greater need for stimulation - are more receptive to new purchase channels; for them, the perceived value of e-reservations is more likely to improve their satisfaction with their experiences at hotels.

Additionally, if we consider a $90 \%$ confidence level, we find that the effect of star rating on overall attitudes toward hotels differs significantly for groups with high or low tendencies to seek variety in their travel experiences. The results indicate that for those people with a low propensity to seek variety or who are less open to new experiences and risks, this quality or reputation signal exerts an important influence on the positive predisposition towards the hotel or hotel chain, whereas for those with high tendency to seek variety the influence of this quality signal is not decisive in the overall attitudes or feelings towards the hotel. This is consistent with previous literature, which indicates that variety seekers tend to pursue more hedonic than functional aspects (Ha and Jang, 2013a).

Our results also show that the influence of overall attitudes toward hotels on satisfaction with specific experience at the hotels, and the influence of satisfaction on behavioral intentions toward hotels/hotel chains, differs significantly for groups with high or low tendencies to seek variety in their travel experiences. In particular, we find that coefficients associated with these relationships are higher for travelers who have low tendencies to seek variety. Although travelers may have positive overall feelings toward particular hotels, the influence of those feelings on their subsequent evaluations of their service experiences may diminish if they exhibit a greater propensity to acquire new experiences and visit different places or environments, because of their need for stimulation and their desire to avoid boredom or saturation. Similarly, even if travelers are satisfied with their stays, the positive effect of their evaluations on their subsequent behavioral intentions toward hotels is greater when they are less inclined to seek variety.

Thus, travelers' variety-seeking levels exert a moderating effect on their overall relationships with hotels or hotel chains. Although attitudes and satisfaction are key factors in behavioral intentions, travelers' decision-making (e.g. about hotel accommodations) is determined by exploratory behaviors such as variety seeking. In particular, high levels of variety seeking are associated with less intention to return to hotels, recommend them, or tolerate price increases at the hotels. Those who are more inclined to seek variety may choose other known alternatives or new brands or providers next time (Ha and Jang, 2013b; Sánchez-García et al., 2012) and be less
Website quality and star rating signals on booking intention 
SJME

25,1

likely to recommend hotels they previously patronized. This tendency has clear implications for company performance (Nieto et al., 2014; Nieto-García et al., 2017).

These results are in line with those of other tourism sector researchers, such as SánchezGarcía et al. (2012), who find that even though consumers may have been satisfied with, and not regretful about, their chosen holiday destinations, they could not return in the short term because of their tendencies to seek variety. Accordingly, we can conclude that the moderating effect of variety seeking occurs independently of the purchase channel, that is, whether consumers book offline or online. Furthermore, the results suggest that travelers with a high propensity to seek variety are more demanding than those with a low variety seeking level. Individuals with a high variety seeking look for new experiences or stimuli to meet their OSL level; but, according to Lashkova et al. (2019), sensory experiences associated with hedonic products (atmospherics and environment of the hotel, in this case) involve learning that generates higher consumer expectations, making consumers more demanding and leading them to seek new sensations. This is consistent with the results found by Lai and Hitchcock (2017), which show that the attributes that provided satisfaction to the guests varied depending on the frequency of accommodation (new, repeat and frequent travelers). Likewise, the Ha and Jang (2013b) study indicates that people with a greater tendency to seek variety or novelty are more sensitive to overall boredom or satiation than those with a lower propensity to seek variety.

\subsection{Managerial implications}

Practically, our findings offer guidance for marketing professionals and hotel managers.

First, this study sheds light on the relevance of booking websites and star rating in establishing customer loyalty, developing long-term relationships with guests and ensuring the performance and continuity of their firms.

Regarding booking website relevance, to assist travelers' decision-making, first, these websites must include consistent security and privacy policies, and provide detailed and relevant information about hotel products and services, including available discounts. It is key that information provided by different channels be complete and consistent with company image. Consumers use multiple channels during their decision-making process, so hotel companies must offer seamless experiences on their channels. In addition to organizational or formal online information, it is necessary to account for the informal information or reviews of other consumers, that is, electronic word-of-mouth (e-WOM). Consumers regard the opinions of other users as more objective than organizational messages, so this type of information can reduce consumers' uncertainty. In addition, to provide satisfactory user experiences, it is also essential for websites to be intuitive and easy to use; provide good quality navigation; and offer simple purchasing, reservation and cancelation processes. Furthermore, hotel websites should be aesthetically attractive and include truthful photographs. Photos should show the facilities and style of the hotel, to stimulate the traveler and make the hotel experience seem tangible. Finally, it is key for website features to meet the requirements of various electronic devices. If during the first contact or search process, a website does not meet the user's needs, the user will not only be discouraged from purchasing or booking but also will develop a negative image of the hotel's or hotel chain's services.

Our study also demonstrates that the number of stars acts as a signal of overall hotel quality; it determines consumer expectations, influences satisfaction with service experiences and affects future behavioral intentions. Hotel companies must meet the expectations of these classifications. In addition to meeting minimum physical and technical requirements, it is essential for hotels to provide personalized levels of service to guests and carry out adequate maintenance and conservation of all facilities and services, especially in higher categories. They should also clearly display their classifications in all possible 
channels, such as their own websites, their brands' websites, and all third-party websites on which they distribute their products. This quality signal favors consumers' hotel search, selection and purchase processes, especially those with a low tendency to seek variety.

Second, this study shows that hotel managers should identify customers who have greater propensity to seek variety in their trips by implementing systems to collect data about customers' tastes and preferences; in this way, they can develop appropriate retention policies for this segment and apply successful inbound marketing strategies. For this type of guest, hotels are advised to modify their environments or servicescapes frequently, such as by changing the decoration of guestrooms or the music, scent, and design of public areas (e.g. lobbies, lounges). They should vary service features, such as restaurant menus or sport and spa services and provide technologies that enrich guests' hotel experiences and their trips as a whole. For example, they could offer mobile applications that allow customers, once registered, to be informed about prices and offers, make inquiries, book quickly and easily and manage check-in and check-out processes. Such applications can also keep guests informed about hotel activities and services, local tourist routes and events (e.g. museums, shows), local transport, and shopping. The goal is to make it possible for guests who wish to experience new or varied sensations, both during their purchase process and when they visit/revisit hotels, to avoid a sense of routine and thus improve service satisfaction. In competitive environments, it is necessary to adapt to each consumer segment by personalizing their services and generating unique experiences.

\subsection{Limitations and further research}

Our work has two main limitations. First, our sample size is limited. Although structural equation modeling by PLS has the ability to handle relatively small sample sizes, it would be advisable to obtain larger samples. Second, our sample includes those who traveled not only for leisure but also for business (13.1\%). Although we analyze the relationship developed between guests and hotel companies, rather than guests' reasons for choosing hotels, it would be advisable to ask business travelers about the degree to which they were involved in their hotel choice, to specify that relationship in more detail.

In terms of future research, we identify five directions. First, researchers could use a panel rather than an ad hoc study. Second, they could examine the moderating effect of variety seeking by taking into account specific situations of travelers (e.g. traveling with family, as a couple or with friends). Third, even though we analyze the moderating effect of travelers' variety-seeking or intrinsically motivated behavior, it would be interesting to analyze the moderating effect of derived varied behavior, that is, behavior caused by external factors such as price promotions or location. Fourth, more surveys about leisure and business travelers or both could be collected and thus we would be able to assess the user experience. Fifth, it would be interesting to replicate the results of this study with other types of accommodation (e.g. rural lodging and tourist apartments) or other types of service (e.g. restaurants).

\section{References}

Abrate, G. and Viglia, G. (2016), "Strategic and tactical price decisions in hotel revenue management", Tourism Management, Vol. 55, pp. 123-132.

Abrate, G., Capriello, A. and Fraquelli, G. (2011), "When quality signals talk: evidence from the Turin hotel industry”, Tourism Management, Vol. 32 No. 4, pp. 912-921.

Álvarez, M. and Asugman, G. (2006), "Explorers versus planners: a study of Turkish tourists", Annals of Tourism Research, Vol. 33 No. 2, pp. 319-338.

Amaro, S. and Duarte, P. (2015), “An integrative model of consumers' intentions to purchase travel online”, Tourism Management, Vol. 46, pp. 64-79.
Website quality and star rating signals on booking intention 
SJME

25,1

Ariffin, A.A.M. and Maghzi, A. (2012), "A preliminary study on customer expectations of hotel hospitality: influences of personal and hotel factors", International Journal of Hospitality Management, Vol. 31 No. 1, pp. 191-198.

Baltas, G., Kokkinaki, F. and Loukopoulou, A. (2017), "Does variety seeking vary between hedonic and utilitarian products? The role of attribute type", Journal of Consumer Behaviour, Vol. 16 No. 6, pp. 1-12.

Barreda, A.A., Bilgihan, A., Nusair, K. and Okumus, F. (2016), "Online branding: development of hotel branding through interactivity theory", Tourism Management, Vol. 57, pp. 180-192.

Barroso, C., Martín, E. and Martín, D. (2007), "The influence of market heterogeneity on the relationship between a destination's image and tourists' future behavior", Tourism Management, Vol. 28 No. 1, pp. 175-187.

Becerra, M., Santaló, J. and Silva, R. (2013), "Being better vs. being different: differentiation, competition, and pricing strategies in the Spanish hotel industry", Tourism Management, Vol. 34, pp. 71-79.

Bergen, M., Dutta, S. and Walker Jr, O.C. (1992), "Agency relationships in marketing: a review of the implications and applications of agency and related theories", Journal of Marketing, Vol. 56 No. 3, pp. 1-24.

Berné, C., Múgica, J.M. and Yagüe, M.J. (2001), “The effect of variety-seeking on customer retention in services", Journal of Retailing and Consumer Services, Vol. 8 No. 6, pp. 335-345.

Bigné, J.E., Sánchez, I. and Andreu, L. (2009), "The role of variety seeking in short and long run revisit intentions in holiday destinations", International Journal of Culture, Tourism and Hospitality Research, Vol. 3 No. 2, pp. 103-115.

Carlson, J. and O' Cass, A. (2011), "Managing web site performance taking account of the contingency role of branding in multi-channel retailing", Journal of Consumer Marketing, Vol. 28 No. 7, pp. 524-531.

Casaló, L.V., Flavián, C., Guinalíu, M. and Ekinci, Y. (2015), "Do online hotel rating schemes influence booking behaviors?”, International Journal of Hospitality Management, Vol. 49, pp. 28-36.

Chang, H.H. and Chen, S.W. (2008), "The impact of online store environment cues on purchase intention: trust and perceived risk as a mediator", Online Information Review, Vol. 32 No. 6, pp. 818-841.

Chang, E.-C. and Tseng, Y.-F. (2013), "Research note: E-store image, perceived value and perceived risk", Journal of Business Research, Vol. 66 No. 7, pp. 864-870.

Chen, Y.-H., Chien, S.-H., Wu, J.-J. and Tsai, P.-Y. (2010), "Impact of signals experience on trust trusting behavior", Cyberpsychology, Behavior, Social Networking, Vol. 13 No. 5, pp. 539-546.

Chien-Huang, L. and Hung-Chou, L. (2012), "Effects of mood states on variety seeking: the moderating roles of personality", Psychology and Marketing, Vol. 29 No. 3, pp. 157-166.

Chin, W.W. (1998), "Issues and opinions on structural equation modeling", MIS Quarterly, Vol. 19 No. 2, pp. 7-16.

Chin, W.W. (2010), "How to write up and report PLS analyses”, in Vinzi, V.E., Chin, W.W., Henseler, J. and Wang, H. (Eds), Handbook of Partial Least Squares: Concepts, Methods and Applications in Marketing and Related Fields, Springer, Berlin, pp. 655-690.

Cohen, J. (1988), Statistical Power Analysis for the Behavioral Sciences, Academic Press, New York, NY.

Dedeke, A. (2016), "Travel web-site design: Information task-fit, service quality and purchase intention”, Tourism Management, Vol. 54, pp. 541-554.

Ekinci, Y., Dawes, P.L. and Massey, G.R. (2008), "An extended model of the antecedents and consequences of consumer satisfaction for hospitality services", European Journal of Marketing, Vol. 42 Nos 1/2, pp. 35-68.

El-Adly, M.I. (2019), "Modelling the relationship between hotel perceived value, customer satisfaction, and customer loyalty", Journal of Retailing and Consumer Services, Vol. 50, pp. 322-332.

Ellis, D. and Mattison Thompson, F. (2018), "The effect of wine knowledge type on variety seeking behavior in wine purchasing", Journal of Wine Research, Vol. 29 No. 2, pp. 71-86. 
Fernández-Herrero, M., Hernández-Maestro, R.M. and González-Benito, O. (2018), "Autonomy in trip planning and overall satisfaction", Journal of Travel and Tourism Marketing, Vol. 35 No. 2, pp. 119-129.

Fishbein, M. and Azjen, J. (1975), Belief, Attitude, Intention and Behaviour: An Introduction to Theory and Research, Addison-Wesley: Reading, MA.

Fong, L.H.N., Lam, L.W. and Law, R. (2017), "How locus of control shapes intention to reuse mobile apps for making hotel reservations: evidence from Chinese consumers", Tourism Management, Vol. 61, pp. 331-342.

Fornell, C. and Larcker, D.F. (1981), "Evaluating structural equation models with unobservable variables and measurement error", Journal of Marketing Research, Vol. 18 No. 1, pp. 39-50.

Geisser, S. (1975), "The predictive sample reuse method with applications", Journal of the American Statistical Association, Vol. 70 No. 350, pp. 320-328.

Hahn, S.E., Sparks, B., Wilkins, H. and Jin, X. (2017), "E-service quality management of a hotel website: a scale and implications for management", Journal of Hospitality Marketing and Management, Vol. 26 No. 7, pp. 694-716.

Hair, J.F., Sarstedt, M., Hopkins, L. and Kuppelwieser, V.G. (2014), "Partial least squares structural equation modeling (PLS-SEM): an emerging tool in business research", European Business Review, Vol. 26 No. 2, pp. 106-121.

Hair, J.F., Sarstedt, M., Ringle, C.M. and Mena, J.A. (2012), "An assessment of the use of partial least squares structural equation modeling in marketing research", Journal of the Academy of Marketing Science, Vol. 40 No. 3, pp. 414-433.

Ha, J. and Jang, S. (2013a), "Determinants of diners' variety seeking intentions", Journal of Services Marketing, Vol. 27 No. 2, pp. 155-165.

Ha, J. and Jang, S. (2013b), "Variety seeking in restaurant choice and its drivers", International Journal of Hospitality Management, Vol. 32, pp. 155-168.

Han, H., Kim, Y. and Kim, E.-K. (2011), "Cognitive, affective, conative, and action loyalty: testing the impact of inertia", International Journal of Hospitality Management, Vol. 30 No. 4, pp. 1008-1019.

Henseler, J., Ringle, C.M. and Sarstedt, M. (2015), "A new criterion for assessing discriminant validity in variance-based structural equation modeling", Journal of the Academy of Marketing Science, Vol. 43 No. 1, pp. 115-135.

Henseler, J., Ringle, C.M. and Sarstedt, M. (2016), “Testing measurement invariance of composites using partial least squares", International Marketing Review, Vol. 33 No. 3, pp. 405-431.

Henseler, J., Ringle, C.M. and Sinkovics, R.R. (2009), "The use of partial least squares path modeling in international marketing", Advances in International Marketing, Vol. 20, pp. 277-319.

Herhausen, D., Kleinlercher, K., Verhoef, P.C., Emrich, O. and Rudolph, T. (2019), “Loyalty formation for different customer journey segments", Journal of Retailing, Vol. 95 No. 3, pp. 9-29.

Hernández-Méndez, J. and Muñoz-Leiva, F. (2015), "What type of online advertising is most effective for eTourism 2.0? An eye tracking study based on the characteristics of tourists", Computers in Human Behavior, Vol. 50, pp. 618-625.

Hernández-Maestro, R.M., Muñoz-Gallego, P.A. and Santos-Requejo, L. (2007), "The moderating role of familiarity in rural tourism in Spain", Tourism Management, Vol. 28 No. 4, pp. 951-964.

Inman, J.J. (2001), "The role of sensory-specific satiety in attribute-level variety seeking", Journal of Consumer Research, Vol. 28 No. 1, pp. 105-120.

Interactive Advertising Bureau (IAB Spain) (2019), “Annual ecommerce study 2019”, available at: https:// iabspain.es/wp-content/uploads/estudio-ecommerce-iab-2019_vcorta2.pdf (accessed 20 June 2020).

Jeon, M.M. and Jeong, M. (2017), "Customers' perceived website service quality and its effects on e-loyalty", International Journal of Contemporary Hospitality Management, Vol. 29 No. 1, pp. 438-457.

Jiang, Z., Wang, W., Tan, B.C.Y. and Yu, J. (2016), "The determinants and impacts of aesthetics in users' first interaction with websites", Journal of Management Information Systems, Vol. 33 No. 1, pp. 229-259.
Website quality and star rating signals on booking intention 
Kim, H.-B. and Kim, W.G. (2005), "The relationship between brand equity and firms' performance in luxury hotels and chain restaurants", Tourism Management, Vol. 26 No. 4, pp. 549-560.

Kim, D. and Perdue, R.R. (2013), "The effects of cognitive, affective, and sensory attributes on hotel choice", International Journal of Hospitality Management, Vol. 35, pp. 246-257.

Kim, J., Kim, P.B. and Kim, J.E. (2018), "Different or similar choices: the effect of decision framing on variety seeking in travel bundle packages", Journal of Travel Research, Vol. 57 No. 1, pp. 99-115.

Kim, W.G., Ma, X. and Kim, D.J. (2006), "Determinants of Chinese hotel customers' e-satisfaction and purchase intentions", Tourism Management, Vol. 27 No. 5, pp. 890-900.

Kirmani, A. and Rao, A.R. (2000), "No pain, no gain: a critical review of the literature on signaling unobservable product quality", Journal of Marketing, Vol. 64 No. 2, pp. 66-79.

Lai, I.K.W. and Hitchcock, M. (2017), "Sources of satisfaction with luxury hotels for new, repeat, and frequent travelers: a PLS impact-asymmetry analysis", Tourism Management, Vol. 60, pp. 107-129.

Lashkova, M., Antón, C. and Camarero, C. (2019), "Dual effect of sensory experience: engagement vs diversive exploration", International Journal of Retail and Distribution Management, Vol. 48 No. 2, pp. 128-151.

Legohérel, P., Hsu, C.H.C. and Daucé, B. (2015), "Variety-seeking: using the CHAID segmentation approach in analyzing the international traveler market”, Tourism Management, Vol. 46, pp. 359-366.

Li, L., Peng, M., Jiang, N. and Law, R. (2017), "An empirical study on the influence of economy hotel website quality on online booking intentions", International Journal of Hospitality Management, Vol. 63, pp. 1-10.

Liao, Z. and Shi, X. (2017), "Web functionality, web content, information security, and online tourism service continuance", Journal of Retailing and Consumer Services, Vol. 39, pp. 258-263.

Lien, C.H., Wen, M.J., Huang, L.C. and Wu, K.L. (2015), "Online hotel booking: the effects of brand image, price, trust and value on purchase intentions", Asia Pacific Management Review, Vol. 20 No. 4, pp. 210-218.

Martenson, R. (2018), "Curiosity motivated vacation destination choice in a reward and variety-seeking perspective", Journal of Retailing and Consumer Services, Vol. 41, pp. 70-78.

Martín-Fuentes, E. (2016), “Are guests of the same opinion as the hotel star-rate classification system?”, Journal of Hospitality and Tourism Management, Vol. 29, pp. 126-134.

Melo, A.J.D.V.T., Hernández-Maestro, R.M. and Muñoz-Gallego, P.A. (2017), "Service quality perceptions, online visibility, and business performance in rural lodging establishments", Journal of Travel Research, Vol. 56 No. 2, pp. 250-262.

Michaelidou, N. (2012), "A typology of consumers' variety-seeking disposition based on inherent needs”, Journal of Marketing Management, Vol. 28 Nos 5/6, pp. 676-694.

Morosan, C. and Jeong, M. (2008), "Users' perceptions of two types of hotel reservation web sites", International Journal of Hospitality Management, Vol. 27 No. 2, pp. 284-292.

National Institute of Statistics (INE) (2019a), "Spain in figures 2019", available at: www.ine.es/ss/ Satellite?L=es_ES\&c=INEPublicacion_C\&cid=1259924856416\&p=1254735110672\&pagename= ProductosYServicios\%2FPYSLayout\&param1=PYSDetalleGratuitas (accessed 20 June 2020).

National Institute of Statistics (INE) (2019b), "Tourism satellite account of Spain (CSTE). Statistical Review 2019. Series 2016-2018”, press releases of December 23, 2019, available at:www.ine.es/ dyngs/INEbase/es/operacion.htm?c=Estadistica_C\&cid=1254736169169\&menu=ultiDatos\&idp= 1254735576863 (accessed 20 June 2020).

National Observatory of Telecommunications and the Information Society (ONTSI) (2019), "Study on electronic commerce B2C 2018", (Edition 2019), Madrid: ONTSI, available at: www.ontsi.red.es/ index.php/es/estudios-e-informes/el-comercio-electronico-b2c-en-espana-2018-edicion-2019 (accessed 20 June 2020).

Nieto, J., Hernández-Maestro, R.M. and Muñoz-Gallego, P.A. (2014), "Marketing decisions, customer reviews, and business performance: the use of the toprural website by spanish rural lodging establishments", Tourism Management, Vol. 45, pp. 115-123. 
Nieto-García, M., Muñoz-Gallego, P.A. and González-Benito, O. (2017), “Tourists' willingness to pay for an accommodation: the effect of eWOM and internal reference price", International Journal of Hospitality Management, Vol. 62, pp. 67-77.

Noone, B.M. and Mattila, A.S. (2009), "Hotel revenue management and the internet: the effect of price presentation strategies on customers' willingness to book", International Journal of Hospitality Management, Vol. 28 No. 2, pp. 272-279.

Núñez-Serrano, J.A., Turrión, J. and Velázquez, F.J. (2014), "Are stars a good indicator of hotel quality? Asymmetric information and regulatory heterogeneity in Spain", Tourism Management, Vol. 42, pp. $77-87$.

Olsen, S.O., Tudoran, A.A., Honkanen, P. and Verplanken, B. (2016), "Differences and similarities between impulse buying and variety seeking: a personality-based perspective", Psychology and Marketing, Vol. 33 No. 1, pp. 36-47.

Park, S. and Huang, Y. (2017), "Motivators and inhibitors in booking a hotel via smartphones", International Journal of Contemporary Hospitality Management, Vol. 29 No. 1, pp. 161-178.

Pereira, H.G., Salgueiro, M. and Rita, P. (2016), "Online purchase determinants of loyalty: the mediating effect of satisfaction in tourism", Journal of Retailing and Consumer Services, Vol. 30, pp. 279-291.

Phelan, K.V., Christodoulidou, N., Countryman, C.C. and Kistner, L.J. (2011), "To book or not to book: the role of hotel web site heuristics", Journal of Services Marketing, Vol. 25 No. 2, pp. 134-148.

Ponte, E.B., Carvajal-Trujillo, E. and Escobar-Rodríguez, T. (2015), "Influence of trust and perceived value on the intention to purchase travel online: integrating the effects of assurance on trust antecedents", Tourism Management, Vol. 47, pp. 286-302.

Radojevic, T., Stanisic, N. and Stanic, N. (2015), "Ensuring positive feedback: factors that influence customer satisfaction in the contemporary hospitality industry", Tourism Management, Vol. 51, pp. 13-21.

Reinartz, W., Haenlein, M. and Henseler, J. (2009), "An empirical comparison of the efficacy of covariance-based and variance-based SEM", International Journal of Research in Marketing, Vol. 26 No. 4, pp. 332-344.

Ringle, C.M., Wende, S. and Becker, J.-M. (2015), SmartPLS 3, SmartPLS GmbH: Boenningstedt.

Rodríguez-Torrico, P., San José, R. and San-Martín, S. (2017), "Tell me what they are like and I will tell you where they buy. An analysis of omnichannel consumer behavior", Computers in Human Behavior, Vol. 68, pp. 465-471.

Rong, J., Li, G. and Law, R. (2009), "A contrast analysis of online hotel web service purchasers and browsers", International Journal of Hospitality Management, Vol. 28 No. 3, pp. 466-478.

Sánchez, J., Callarisa, L., Rodríguez, R.M. and Moliner, M.A. (2006), "Perceived value of the purchase of a tourism product", Tourism Management, Vol. 27 No. 3, pp. 394-409.

Sánchez-Fernández, R., Gallarza, M. and Arteaga, F. (2020), "Adding dynamicity to consumer value dimensions: an exploratory approach to intrinsic values and value outcomes in the hotel industry", International Journal of Contemporary Hospitality Management, Vol. 32 No. 2, pp. 853-870.

Sánchez-García, I., Pieters, R., Zeelenberg, M. and Bigné, E. (2012), "When satisfied consumers do not return: Variety seeking's effect on short- and long-term intentions”, Psychology and Marketing, Vol. 29 No. 1, pp. 15-24.

San-Martín, S. and Camarero, C. (2009), "How perceived risk affects online buying", Online Information Review, Vol. 33 No. 4, pp. 629-654.

San-Martín, S. and Jimenez, N. (2017), "Curbing electronic shopper perceived opportunism and encouraging trust", Industrial Management and Data Systems, Vol. 117 No. 10, pp. 2210-2226.

San-Martín, S., Camarero, C. and San José, R. (2011), "Dual effect of perceived risk on cross-national ecommerce", Internet Research, Vol. 21 No. 1, pp. 46-66.

San-Martín, S., López-Catalán, B. and Ramón-Jerónimo, M.A. (2015), "Signalling as a means to generate loyalty in m-commerce: does shopper experience moderate the process?", Journal of Customer Behaviour, Vol. 14 No. 3, pp. 235-256.
Website quality and star rating signals on booking intention 
SJME

25,1

SEGITTUR (2014), "Impact of innovation and new technologies on the habits of new tourists in Spain", available at: www.segittur.es/es/sala-de-prensa/detalle-documento/ESTUDIO-El-impacto-de-lainnovacin-y-las-nuevas-tecnologas-en-los-hbitos-del-nuevo-turista-en-Espaa-/\#.XIrTzaBKgdU (accessed 20 June 2020).

Sohn, H.K., Lee, T.J. and Yoon, Y.S. (2016), "Relationship between perceived risk, evaluation, satisfaction, and behavioral intention: a case of local-festival visitors", Journal of Travel and Tourism Marketing, Vol. 33 No. 1, pp. 28-45.

Stone, M. (1974), "Cross-validatory choice and assessment of statistical predictions", Journal of the Royal Statistical Society: Series B (Methodological), Vol. 36 No. 2, pp. 111-147.

Su, L., Swanson, S.R., Chinchanachokchai, S., Hsu, M.K. and Chen, X. (2016), "Reputation and intentions: the role of satisfaction, identification, and commitment", Journal of Business Research, Vol. 69 No. 9, pp. 3261-3269.

Sukhu, A., Choi, H., Bujisic, M. and Bilgihan, A. (2019), "Satisfaction and positive emotions: a comparison of the influence of hotel guests' beliefs and attitudes on their satisfaction and emotions", International Journal of Hospitality Management, Vol. 77, pp. 51-63.

Sun, J. (2014), "How risky are services? An empirical investigation on the antecedents and consequences of perceived risk for hotel service", International Journal of Hospitality Management, Vol. 37, pp. 171-179.

Tankovic, A.C. and Benazic, D. (2018), "The perception of e-servicescape and its influence on perceived e-shopping value and customer loyalty", Online Information Review, Vol. 42 No. 7, pp. 1124-1145.

Theodosiou, M. and Katsikea, E. (2012), "Antecedents and performance of electronic business adoption in the hotel industry", European Journal of Marketing, Vol. 46 Nos 1/2, pp. 258-283.

Van Trijp, H.C.M., Hoyer, W.D. and Inman, J.J. (1996), "Why switch? Product-category level explanations for true variety-seeking behavior", Journal of Marketing Research, Vol. 33 No. 3, pp. 281-292.

Viejo-Fernández, N., Sanzo-Pérez, M. and Vázquez-Casielles, R. (2019), "Different kinds of research shoppers, different cognitive-affective consequences”, Spanish Journal of Marketing - ESIC, Vol. 23 No. 1, pp. 45-68.

Wang, L., Law, R., Guillet, B.D., Hung, K. and Fong, D.K.C. (2015), "Impact of hotel website quality on online booking intentions: eTrust as a mediator", International Journal of Hospitality Management, Vol. 47, pp. 108-115.

Wang, H.-Y. and Wang, S.-H. (2010), "Predicting mobile hotel reservation adoption: Insight from a perceived value standpoint", International Journal of Hospitality Management, Vol. 29 No. 4, pp. 598-608.

Williams, P. and Soutar, G.N. (2009), "Value, satisfaction and behavioral intentions in an adventure tourism context", Annals of Tourism Research, Vol. 36 No. 3, pp. 413-438.

Wong, J. and Law, R. (2005), "Analysing the intention to purchase on hotel websites: a study of travellers to Hong Kong”, International Journal of Hospitality Management, Vol. 24 No. 3, pp. 311-329.

Wong, J., Wu, H. and Cheng, C. (2015), "An empirical analysis of synthesizing the effects of festival quality, emotion festival image and festival satisfaction on festival loyalty: a case study of Macau food festival", International Journal of Tourism Research, Vol. 17 No. 6, pp. 521-536.

\section{Corresponding author}

Tamara Belver-Delgado can be contacted at: tamarabd@usal.es

For instructions on how to order reprints of this article, please visit our website:

www.emeraldgrouppublishing.com/licensing/reprints.htm

Or contact us for further details: permissions@emeraldinsight.com 